\title{
Racionais MC's, Marighella e o branqueamento do Brasil
}

\author{
Racionais MC's, Marighella, and the Whitening of Brazil \\ Racionais Mc's, Marighella y el blanqueamiento de Brasil
}

Paulo Dutra

\section{Resumo}

Neste trabalho são discutidos aspectos que circundam o contexto da produção artística e intelectual de representantes da diáspora africana no Brasil com o objetivo de se enfatizar como tal produção e sua recepção passam por um sistemático processo de deturpação que desemboca em aproximações, análises e conclusões baseadas em pressupostos branqueadores.

Palavras-chave: Racionais MC's, Carlos Marighella, raça.

\begin{abstract}
In this paper I examine aspects that surround the context of the artistic and intellectual production of representatives of the African diaspora in Brazil. My goal is to highlight how such a production and its reception go through a systematic process of distortion that leads to approaches, analyzes, and conclusions that are based on a process of whitening.
\end{abstract}

Keywords: Racionais MC's, Carlos Marighella, race.

\section{Resumen}

Este artículo examina aspectos que rodean el contexto de la producción artística e intelectual de representantes de la diáspora africana en Brasil. El objetivo es demonstrar cómo dicha producción y su recepción pasan por un proceso sistemático de distorsión que conduce a enfoques, análisis y conclusiones que están basados en el proceso de blanqueamiento.

Palabras-clave: Racionais MC's, Carlos Marighella, raza.

Existe um processo de deturpação, ${ }^{1}$ ainda em ampla execução, implementado por meio dos mais variados mecanismos aos quais a produção artística, cultural e intelectual da diáspora africana no Brasil é sistematicamente submetida desde que as primeiras vítimas dos sequestros - impingidos a um sem-número de africanos - aqui desembarcaram. ${ }^{2}$ Tal fato, apesar de facilmente detectado em todas as esferas da sociedade brasileira, ${ }^{3}$ ainda precisa amiúde ser re(a)presentado, demonstrado, teorizado, exposto e denunciado, por meio das mais variadas manifestações, tanto de ordem cultural quanto intelectual, da comunidade negra e de seus simpatizantes. Para tanto, proponho aqui uma leitura do rap dos Racionais MC's, concentrando-me no clipe Mil faces de um homem leal (2012), gravado em homenagem a Carlos Marighella, e, a partir disso, demonstrar como a crítica, sobretudo a acadêmica, também acaba por contribuir para esse processo de deturpação da produção artística dos afrodescendentes.

\footnotetext{
* The University of New Mexico (UNM), Albuquerque, NM, Estados Unidos. (Dorcid.org/0000-0003-0013-4239. E-mail: pdutra@unm.edu

${ }^{1}$ E devo advertir que, em nenhum momento, emprego o termo com conotação pejorativa. O mesmo deve ser entendido aqui em proximidade com a ideia de descaracterização e ou distorção.

2 Esse processo se vincula intrinsecamente àquele projeto ideológico de branqueamento dos brasileiros observado por diversos estudiosos, a exemplo de Duarte (2007), Vital (2012), Dávila (2003) e Carone e Bento (2002), para ficar somente em alguns nomes no século XXI. E, mesmo que se leve em consideração que o processo de branqueamento físico (populacional, empírico) tenha fracassado, conforme aponta Munanga (2004, p. 137), nos âmbitos da ideologia e do campo simbólico ele continua vivo e em marcha.

${ }^{3} \mathrm{Na}$ televisão, nos livros didáticos, na literatura, enfim, virtualmente em todos os setores.
} 
Há muitos mecanismos pelos quais o processo de distorção opera. Oportunamente, neste trabalho, somente dois deles serão discutidos: o apagamento da figura do/a afrodescendente e o branqueamento de suas obras, ${ }^{4}$ principalmente nos meios pelos quais o discurso acadêmico se propaga. Tais mecanismos arrojam a dita produção e a sua recepção num sistemático processo que desemboca em aproximações, análises e, via de regra, conclusões que, apesar de enriquecerem as disciplinas, não contemplam plenamente o objeto. Isso acontece inclusive porque determinadas abordagens terminam por se configurar, em certa medida, como um mecanismo a mais pelo qual opera a manutenção da supracitada deturpação. Demonstrarei, então, nas páginas seguintes, como a obra dos Racionais MC's se inscreve nesse processo histórico e recorro ao já citado clipe Mil faces de um homem leal (2012) para demonstrar tanto a consciência do grupo em relação à existência do problema aqui posto quanto para ilustrar como, apesar disso, o discurso acadêmico, que no momento goza de mais prestígio, sutilmente embranquece a produção desses representantes da diáspora africana.

Hoje, no Brasil, os Racionais MC's já dispensam apresentações. Em todo o caso: são um grupo, pioneiro no rap, formado por quatro jovens oriundos das periferias da maior e mais abastada metrópole brasileira e de um contexto de avivamento das discussões das relações raciais. Reconhecida como a capital financeira do país, São Paulo é um polo industrial, que se apresenta também como um fértil polo cultural. Assim, além de exercer grande atração migratória, também exporta seus produtos culturais para o resto do Brasil na forma de arte, costumes e, obviamente, ideários políticos. Desse contexto surgiram os Racionais $\mathrm{MC}^{\prime} \mathrm{s}$, que influenciados tanto pelos movimentos negros do exterior como por um processo de enfraquecimento do velho mito da democracia racial que se tentou impor no Brasil durante várias décadas - vieram a se tornar uma importante voz da população negra um século depois da abolição da escravatura. Avessos aos apelos da mídia brasileira, ao denunciarem, por meio de ritmo e poesia, o racismo endêmico, as mazelas impostas à população afrodescendente e o cotidiano das periferias de São Paulo, alcançaram a façanha de vender centenas de milhares de cópias nos anos 1990 sem recorrerem ao arcabouço logístico do qual as grandes gravadoras e emissoras de rádio e televisão costumam dispor.

De maneira não gratuita, já há vários trabalhos acadêmicos nas disciplinas das Ciências Humanas a eles dedicados e os meios acadêmicos, a seu modo, vieram a ratificar o que nas ruas já se atestava: a ímpar qualidade artística da produção do grupo, sua apurada consciência linguística e o diálogo que estabelecem com seu contexto de produção (Dutra, 2015). Apesar disso, o aqui referenciado clipe: Mil faces de um homem leal (2012), que foi eleito o melhor do ano em 2012 (MTV Video Music Brasil), não despertou à época, pode-se dizer, a mesma atenção. Esse desinteresse pode ser explicado por vários motivos, dentre eles o destaque à, hoje apagada, figura do antigo inimigo número um da ditadura.

Devido a esse apagamento simbólico e cultural é que, por longas décadas, tornou-se pouco conhecido o baiano Carlos Marighella (1911-1969), que foi membro ativo do Partido Comunista Brasileiro (1930), deputado federal (1945), e teve sua trajetória pessoal intrinsecamente atrelada à sua trajetória política. Notório pelos seus discursos enquanto deputado, o ex-aluno da Escola Politécnica da Bahia também ficou famoso pelo episódio em que respondeu a uma questão de um exame de física em forma de poema. Marighella conheceu a prisão pela primeira vez após criticar, também por meio de um poema, a atuação do então interventor Juracy Magalhães. Depois de uma vida marcada por anos de encarceramento em diferentes ocasiões e de vida clandestina em outras, devido a sua filiação ao Partido Comunista, na região sudeste - eixo político do Brasil à época - durante distintos governos (desde a Era Vargas ao contexto conturbado do Brasil pós golpe militar de 1964), Marighella foi assassinado em uma emboscada arquitetada por agentes da ditadura no ano de 1969 na cidade de São Paulo.

\footnotetext{
${ }^{4}$ A "Demonização" é outro dos vários mecanismos, que, porém, não será abordado nesta oportunidade.
} 
Depois de sua morte, com a sistemática e progressiva associação de sua imagem à de um criminoso comum, ${ }^{5}$ o legado intelectual e político de um dos mais importantes revolucionários brasileiros passou a ser apagado dos registros históricos. Em 2012, porém, Mário Magalhães publicou a mais respeitada entre as escassas biografias do ex-deputado e esse trabalho, assim como o documentário Marighella de Isa Grispum Ferraz (2012) e o referido clipe dos Racionais MC's (dirigido por Daniel Grispum) reinseriram, ainda que momentaneamente, a figura de Carlos Marighella no cenário das discussões no Brasil. ${ }^{6}$

No clipe, a primeira imagem que surge é o número 1969, que é imediatamente substituído por 2012. A partir de então, as duas imagens se sobrepõem constantemente e em alta velocidade. Assim, apresenta-se uma sobreposição de duas épocas que, doravante, condensam-se e tornam-se uma. Tal efeito é já uma metonímia de todo o videoclipe, pois elementos das duas épocas se alternarão no seu decorrer. Vê-se a porta da Rádio Nacional e a parte técnica da apresentação do clipe começa. Os nomes do grupo, da Rádio e do clipe estão escritos com a mesma fonte. Um porteiro negro ${ }^{7}$ junta-se à cena que, condizente com as construções do rap, traz o reincidente chiado de pneus, de cujo carro saem os integrantes do grupo. A câmera vagueia e se congela por um instante em uma das figuras; há um flash e vemos Mano Brown vestido a caráter, não em seu visual típico dos rappers, mas à moda dos anos de 1960. É a histórica invasão da Rádio agora reencenada. A palavra, então, faz-se presente quando, direcionada àquele porteiro negro, ouvimos a fala "quieto, não quero você não, mano"; enquanto que, já dentro das dependências da Rádio, os termos mudam para palavras de baixo calão. Nitidamente, o assalariado negro é visto como "mano", enquanto os demais presentes são inseridos em outra categoria. O emprego do vocábulo "mano", provavelmente nunca utilizado por Marighella, dá o tom da espécie de ficcionalização, reinterpretação e atualização do evento histórico que se deslinda diante de nossos olhos. Sabe-se que Marighella não estava presente no momento da ação, porém os Racionais $\mathrm{MC}^{\prime} \mathrm{s}$ decidiram perpetuar a lenda de que ele houvesse estado. Vale lembrar que, provavelmente, quem deu início à propagação dessa inverdade foram os agentes da ditadura numa tentativa de aumentar o clima de hostilidade contra a pessoa pública de Marighella. Como é notório o fato de que os Racionais MC's (e os rappers em geral) enfrentam as acusações de serem bandidos "aceitando-as" e transformando-as em elogio, não é de se espantar que a estratégia tenha se repetido em relação ao "bandido da minha cor", referenciado no clipe. ${ }^{8}$

Um diálogo constante entre passado e presente é a base do clipe. À profusão de imagens captadas à época e manchetes de jornais somam-se outras: de comunidades carentes com seus inconfundíveis alto-falantes afixados nos postes, porta-vozes das rádios comunitárias de onde agora emanam as supostas palavras de Marighella, proferidas naquele dia em que o sinal da Rádio Nacional foi hackeado. O recurso é autoevidente. O discurso do "bandido da minha cor", antes direcionado às resistências, agora encontrou um meio de propagação e se direciona às periferias; Brown e Marighella são um só neste momento. E essa transposição indica claramente que, para os moradores da periferia, ainda há uma revolução a ser feita.

\footnotetext{
5 É dado incontestável e sugestivo que, apesar de ter exercitado os mesmos procedimentos para "arrecadar fundos" para as operações e praticado os mesmos atos, considerados criminosos, nenhum dos outros revolucionários de tez clara, que enfrentaram a ditadura, tiveram suas imagens associadas às de criminosos comuns e desenvolvidas dessa forma no imaginário nacional, como ocorreu no caso de Marighella.

${ }^{6}$ Em 2019, Marighella voltou a ser foco das atenções devido ao lançamento de um homônimo longa-metragem dirigido pelo até então ator Wagner Moura.

${ }^{7} \mathrm{O}$ termo negro é aqui, e em diante, usado propositalmente de maneira livre e em contraposição às diversas tentativas de classificação da população brasileira baseada nas diferentes tonalidades da cútis e de acordo com as propostas para o entendimento da identificação do indivíduo negro, apresentadas pelos próprios rappers em suas letras. Como, por exemplo, no rap "Negro Drama": "Negro drama / Cabelo crespo / E a pele escura... O trauma que eu carrego / Pra não ser mais um preto fodido... Me ver pobre preso ou morto já é cultural... Eu sou irmão dos meus truta de batalha... Eu visto preto por dentro e por fora... Uma negra e uma criança nos braços... O bastardo, mais um filho pardo, sem pai... Eu sou o mano / Homem duro do gueto / Brown... Pele parda / Ouço funk..." (Racionais MC's, 2002). Além disso, faço uso também da anedota que circula nestes tempos de cotas raciais e discussão sobre os critérios adotados para a identificação dos detentores do direito a elas (que, apesar de tudo, representa um fato cotidiano na sociedade brasileira): "para determinar com exatidão quem é negro bastaria que os comitês responsáveis por tal tarefa fossem compostos por policiais militares".

${ }^{8}$ Essa associação é dado fundamental para entender como os Racionais MC's lidam com a questão simbólica envolvida na criminalização dos sujeitos negros no Brasil e parece ser mal interpretada por Welter e Pureza (2014).
} 
A técnica usada para dissolver e restabelecer as fronteiras espaço-temporais consiste numa mudança de tons em preto e branco para imagens em cores. E não se trata somente de ser fiel à realidade de uma época que experimentou a transição tecnológica da transmissão monocromática (escalas de cinza) para a em cores, mas também de uma demonstração, em sua relação metafórica, de como o imaginário sobre as relações raciais, ancorado no mito da democracia racial, sugeria tons cinzentos nas películas como busca de certa harmonia entre branco e negro no resultado de tal combinação. Também, por isso, não se pode ignorar o emprego que o grupo faz do valor simbólico das "cores" em sua relação com sua respectiva atribuição de valores. Ainda que o último disco dos Racionais MC's, Cores e valores (2014), não seja o objeto de estudo deste trabalho, aqui se toma emprestado seu título na forma de conceito, para exprimir a indissolubilidade da relação que historicamente se estabeleceu na sociedade brasileira. Na práxis cotidiana, através da história, criou-se um paradigma no mundo objetivo que se estendeu ao campo simbólico e que rege as relações humanas no Brasil em todos seus níveis. Tal paradigma se baseia na pigmentação da tez, que gradativamente se naturalizou, determinando atribuição de valores (morais, éticos, econômicos, etc.) atrelados à cor da pele do indivíduo. Aqui, entende-se então a expressão "cores e valores" não somente como pueril denúncia da existência desse paradigma, mas também como uma resposta à transposição do produto de um mero fenômeno físico de refração ao campo simbólico social na forma de estigma. E essa resposta se dá por meio de uma (re)apropriação simbólica que, a partir de finais do século vinte, exalta a cor negra como parte de uma identidade positiva, afirmativa, definitiva e já não submissa a valores fundamentalmente brancos como parâmetros e medidas para sua circunscrição, desprezando-os, assim, como condição sine qua non para sua existência.

As imagens ainda demonstram uma relevante relação entre a arma de fogo e o microfone, metáfora tão cara aos artistas do rap. Brown, quando representando a si mesmo, diversas vezes aparece portando ora uma pistola, ora um microfone. No seu papel de Marighella, uma vez conquistado o microfone, o rapper apresenta essas duas armas, a simbólica e a real, em condição de igualdade. Intercalam-se reuniões dos grupos revolucionários (ou terroristas, na terminologia policial-governista) com reuniões de manos das periferias (ou bandidos, naquela terminologia), em volta de uma espécie de palco onde um DJ executa suas mixagens. Por meio da difusão dos equipamentos de áudio, seja de uma estação de rádio, seja de uma equipe de som, passado e presente são, literalmente, mixados pelo DJ.

Os becos e vielas, onde proliferam minúsculos cômodos que servem de domicílio para os moradores das comunidades, são contrapostos ao interior de edifícios invadidos e cômodos superlotados. Trata-se, segundo Marlene Bergamo e Laura Capriglione, da "Ocupação Mauá, encravada no meio da cracolândia paulista" (2012, s.p.) e "o cenário do clipe, um antigo hotel no centro da cidade, vizinho à prestigiosa Sala São Paulo, da Orquestra Sinfônica do Estado de São Paulo, e defronte à Estação da Luz, foi invadido há cinco anos por pobres, cortiçados e moradores de rua" (Capriglione e Bergamo, 2012, s.p.). Segundo Tricia Rose "O videoclipe do rap também desenvolveu suas próprias convenções de gênero" e usualmente essas convenções "afirmam as principais preocupações temáticas do rap: identidade e localização" (Rose, 1994, p. 10-11, tradução nossa). A escolha do local para as gravações, então, parece óbvia. Essa sucinta apresentação do clipe, que não ambiciona exaurir as possibilidades de interpretação, serve de pano de fundo para a discussão de um aspecto mais importante, que é justamente o de como o grupo reconstrói a figura de Carlos Marighella, tomando como ponto de partida a questão implícita no binômio "cores e valores", em estreito contraponto com a figura dos rappers e seu papel de porta-vozes de suas comunidades.

Reinaldo Azevedo, cujo histórico de "ataques" ao grupo em seu blog na revista Veja demonstra sua posição em relação aos Racionais $\mathrm{MC}^{\prime} \mathrm{s},{ }^{9}$ também teceu comentários sobre o clipe. Segundo ele, trata-se de homenagem ao "terrorista arrancador de perna e que escreveu um Minimanual da Guerrilha" (Azevedo, 2012, s.p.). Questionar os crimes que Marighella

\footnotetext{
${ }^{9}$ Note-se que Azevedo admite: "É claro que eu nunca ouvi um troço chamado Racionais MC's. Nem vou ouvir" (2007).
} 
cometeu escapa ao escopo deste trabalho, até porque não se encontra nos registros históricos ou biográficos uma negativa, de sua parte, dos crimes que cometeu; somente a respeito daqueles que os agentes da ditadura lhe imputaram para que sobre ele recaísse a culpa. Claro é que Azevedo aloca no mesmo universo Marighella e Brown com uma intenção mais que pejorativa. Porém, segundo Victor Meyer (1999, p. 257): “seus algozes o chamavam de bandido, embora essa qualificação já tenha sido consensualmente afastada pelo pensamento majoritário, que hoje se autodefine democrático". Apesar do otimismo da afirmação, aceitá-la implica supor que, em 2012, quando do lançamento do videoclipe, quem intitulava Marighella de bandido seria somente um pensamento minoritário e, note-se, os Racionais $\mathrm{MC}^{\prime} \mathrm{s} .{ }^{10} \mathrm{~A}$ diferença, obviamente, está no approach, já que, no léxico dos Racionais $M C^{\prime}$ 's, bandido não tem conotação negativa e, na obra aqui em questão, o verbete vem acompanhado do emblemático complemento "da minha cor". Surge, então, a necessidade imperativa de um questionamento a respeito dessa cor de Marighella, que, segundo Mano Brown, é também a sua. Em outras palavras, apresenta-se a questão racial com suas implicações e desdobramentos nesse contexto.

Segundo seus biógrafos, Marighella era descendente de italianos e de haussás sudaneses. $\mathrm{Na}$ maioria dos documentos em que se faz referência a seu biótipo, aquela famosa lacuna "cor" sempre foi preenchida com o vocábulo "branca" e nunca com o, quiçá mais adequado, "parda". Isso, inclusive depois de sua morte, pois, conforme Mário Magalhães (2012, p. 562), "no laudo assinado por ele [Harry Shibata] e o colega, Abeylard Orsini, o mulato Marighella mudou de cor e virou "branco'". O artifício de declarar como branco um cidadão visivelmente mestiço pode ser justificado por razões e de maneiras diversas. ${ }^{11}$ Entretanto, talvez tal preferência tenha se manifestado porque o pai de Marighella, à época, já entendia a indissociável relação entre cores e valores, isso é: "cor de pele branca é também patrimônio na patrimonialista sociedade brasileira" (Nascimento, 2019, p. 200). Além disso, Marighella viveu em uma época em que a ideia da democracia racial já havia começado a substituir a fracassada ideologia do branqueamento biológico da população brasileira. Por isso, quando o assunto migra da esfera da burocracia e rotina tabelionar para a práxis da vida cotidiana do "bandido da minha cor", há uma inversão. Mário Magalhães recorda um dos incidentes ocorridos durante o mandato de Marighella: "o correligionário Dutra se destemperou: 'Não permito que elementos de cor [...] se intrometam no meu discurso.' Marighella chamou-o de racista, mas poucos se incomodaram" (2012, p. 188). O "bandido da minha cor", afinal, somente era branco no papel. ${ }^{12} \mathrm{E}$ essa é uma das razões fundamentais para que os Racionais $\mathrm{MC}^{\prime}$ 's produzissem o rap e seu clipe.

Tangencialmente, assim se apresenta a questão racial nas biografias de Marighella. ${ }^{13}$ No clipe, ela cobra papel principal e os atores que representam os revolucionários (ou terroristas) são todos negros. ${ }^{14}$ Ademais, o clipe é permeado de imagens que fazem alusões às práticas culturais dos afrodescendentes e, de modo simultâneo e direto, aludem aos supostos gostos e práticas pessoais de Marighella, retratado na canção como "super-herói mulato", "assaltante nato" que "honrou a raça". Esses indícios geram um efeito que apresenta dois desdobramentos, um subordinado ao outro. Um dos mecanismos que opera a deturpação é justamente o apagamento sistemático da figura negra na História do Brasil e, no clipe, clama-se por uma inversão da prática de suprimir a presença do negro em papéis de destaque na sociedade brasileira. Agora, é o branco quem tem sua imagem apagada e substituída pela do negro numa tentativa simbólica de redistribuir os elementos que sustentam o binômio "cores e valores".

\footnotetext{
${ }^{10}$ Vale ressaltar que, em 2019, com a corrente orientação ideológica do Estado em contrapartida ao lançamento do longa-metragem dirigido por Wagner Moura, a associação de Marighella à figura de um criminoso comum tem se propagado novamente, aparecendo uma infinitude de memes como material pelas redes sociais e pelos grupos de WhatsApp.

${ }^{11}$ O estudo de Jerry Dávila (2003), Diploma of whiteness, traz bons exemplares dessas razões e maneiras.

${ }^{12}$ Outra vez vale ressaltar o impacto do longa-metragem de Wagner Moura porque miríades de memes sugerem que há ainda um entendimento de que Marighella seria branco e não pardo. Obviamente que a polêmica escolha de Seu Jorge para o papel de Marighella contribui para a problematização do assunto.

${ }^{13}$ Mário Magalhães (2012) parece tentar abordar a questão de maneira mais abrangente em alguns momentos, porém não há de fato uma problematização da mesma.

${ }^{14}$ Que sejam somadas a esse dado as imagens de figuras negras internacionalmente famosas pela luta transnacional contra a opressão imposta pela dominação branca.
} 
A reconstrução da trajetória de Marighella, feita por meio de um recurso artístico caracteristicamente negro, o rap, é claramente uma resposta à maneira passiva como despercebidamente se acolhe o constante processo de deturpação. Vale a pena lembrar que "nada é mais central nas narrativas dos videoclipes do rap do que situar o/a rapper no seu meio, no seu grupo, na sua posse" (Rose, 1994, p. 10, tradução nossa) e, portanto, os Racionais MC's, por meio do clipe, ainda que metaforicamente, devolvem ao mano Marighella sua possessão (se me é permitido o jogo de palavras) mais importante: seu lócus e identidade de intelectual, revolucionário e negro em uma sociedade racista. Foi necessária a intervenção de um grupo de rap para que dois fatos de extrema importância fossem repensados: um deles é o resgate da condição de negro de uma das figuras mais emblemáticas da vida política do Brasil entre os anos de 1934 e 1969 e, obviamente, a que isso se contrapõe: ao apagamento, uma vez mais, do negro e de sua participação nos processos constituintes da sociedade brasileira. O outro fato consiste em como as constantes mixagens das figuras de Brown e Marighella e também do espaço-tempo executadas no clipe demonstram a necessidade de se repensar o período ditatorial e a relação deste com a atual realidade das periferias, onde os horrores da ditadura listados em determinados livros de história, supostamente como parte de um passado longínquo, continuam: tortura (institucionalizada), grupos armados em conflito, supressão de liberdades civis e religiosas, "lei do silêncio", medo, toques de recolher, etc. O clipe deixa claro que o rap é o meio mais eficaz de disseminação da palavra revolucionária no contexto atual do estado ditatorial (simbólico, se assim se preferir) imposto às periferias e a seus sujeitos em todos os níveis.

Apesar de toda proeminência posta acima, o clipe despertou ainda menos interesse no ambiente acadêmico. Detectei a existência somente de dois trabalhos, salvo engano, que exercitam uma análise do mesmo: um, de Juliane Vargas Welter e Fernando Cauduro Pureza (2014), e outro, também de autoria conjunta, de Guilherme Botelho, Walter Garcia e Alexandre Rosa (2015). Dois trabalhos pioneiros e importantes que, porém, apresentam certas questões problemáticas. O segundo reconhece a presença da questão racial em Mil faces de um homem leal (2012) e, inclusive, lembram-nos de que o clipe apresenta diversas figuras famosas (como Angela Davis e Malcolm X, entre outros) por terem alçado suas vozes contra a opressão sofrida por sujeitos negros. No entanto, a história transnacional da luta negra e suas particularidades que os Racionais MC's apresentam categoricamente são interpretadas como apenas uma das partes de uma espécie de processo universal (ainda que brasileiro) de luta de classes. Por sua vez, Welter e Pureza, apesar de também identificarem a categórica reconstrução da figura de Marighella por meio de uma exaltação da questão racial, parecem entender literalmente demais dois elementos e, por isso, talvez concluam que “o Marighella de Mano Brown é um líder defensor do povo, mas desprovido de um conteúdo ideológico claro” (2014, p. 189). Um dos dois elementos é o Manual of urban guerilla, de Marighella (1985) que, como Mário Magalhães (2012) e Gene Hanrahan (1985) já observaram, é muito mais uma obra de ficção do que um efetivo manual de guerrilha. O outro elemento que - baseado em interpretação de Garcia (2013) - é tomado de forma literal é a presença da violência no clipe. Welter e Pureza (2014) parecem desconsiderar ou desconhecer importantes recursos artísticos intrínsecos ao rap que já foram debatidos e explicados por estudiosos nos Estados Unidos há mais de 20 anos. Para ficar somente em um exemplo, cito Russel Potter (1995, p. 83): “desconhecedores do vernáculo dos negros e do 'em modo Sygnifin $(g)$ ' 15 muitos desses ouvintes reagiram contra o que lhes parece ser um discurso obsceno e violento". De fato, Welter e Pureza (2014), por se acercarem ao rap desprovidos de sólido embasamento teórico em relação aos recursos retóricos, estéticos e artísticos específicos empregados em sua produção, leem o rap e o clipe de maneira literal em certos momentos e entendem que há um apagamento do referido manual no clipe. Além disso, concebe-se o Marighella dos Racionais MC's como desprovido de conteúdo ideológico claro porque se desconsidera que "livres do olhar dos brancos, os negros criaram suas próprias estruturas vernaculares únicas e saborearam o jogo duplo que essas formas apresentavam em

\footnotetext{
${ }^{15}$ De acordo com Henry Louis Gates Jr. (1988, p. xxv, tradução nossa.): "Sygnifyin(g) é a figura da voz-dupla, sintetizada pelas representações de Exu, com duas bocas, na escultura".
} 
relação às formas" (Gates Jr., 1988, p. xxiv, tradução nossa.). Se considerarmos, porém, o modo "Sygnifin(g)" (Potter, 1995, p. 83) presente no clipe dos Racionais MC's (e de certa maneira também no manual de Marighella), a relação pode ser vista por outros ângulos.

Como dito, o clipe parece não ter sido de muito interesse para o ambiente acadêmico e me aventuro a apontar razões para o fato, dando vazão ao ponto central dessa discussão. Apesar de já fazerem parte do corpus de estudo das disciplinas de Ciências Humanas, a crítica da obra dos Racionais MC's ainda se encontra em fase tanto de autoafirmação quanto de afirmação da obra. Os estudos, em geral, dedicam-se a comprovar sua "qualidade artística" ou, pelo menos, consagram algumas laudas à tarefa. Em geral, isso se dá por meio de um branqueamento da obra, já que as ferramentas de análise e seus pressupostos baseiam-se em modelos brancos. Esses estudos, fundamentais à inserção da produção dos Racionais $\mathrm{MC}^{\prime}$ 's nos meios acadêmicos, vieram a comprovar o óbvio e acabaram por servir de cartão de apresentação para os especialistas das academias habituados a lidar somente com o "que nos foi ensinado a ser entendido como arte, pintura, literatura" (Nascimento, 2006, p. 15) em seus respectivos manuais.

Essa postura, diante de um grupo já estabelecido no meio artístico, é resultado, em certo modo, tanto do fato de que ainda se associa o rap, aprioristicamente, a um tipo de música popular desprovido de qualidade e para consumo rápido, ${ }^{16}$ quanto da práxis corriqueira no nosso mundo acadêmico de favorecer produções que se envolvam em auras de nobreza, seja pelo seu estilo erudito, seja pela consagração que a história lhes haja concedido. Porém, em certa medida, dita atitude é também resultado do processo de deturpação. Outra razão possível é o fato de que, no meio acadêmico, o rap disputa, em condições desfavoráveis, com as publicações da "Literatura Marginal", a atenção de estudiosos muito mais aptos e afeitos que somos ao estudo da prosa e da poesia convencionais e delas adeptos.

Apesar de parecer ser um equívoco substancial apontar, superficialmente, semelhanças entre o rap e a "Literatura Marginal", não é difícil encontrar assertivas que apresentam tal prática e, portanto, não será surpresa se certas fórmulas destinadas a esta alcançarem também aquele. João Cezar de Castro Rocha, por exemplo, propôs, em artigo homônimo, a "dialética da marginalidade" e admite que a periferia é frutífera enquanto material de estudo, já que inclusive "professores [...] como eu, ganham bolsas no exterior e escrevem artigos sobre a 'dialética da marginalidade" (Rocha, 2006, p. 44). Repetindo certas fórmulas preestabelecidas de approach, Rocha afirma, por exemplo, que Roberto Schwarz "estava certo ao afirmar que 'o romance de estreia de Paulo Lins [...] sobre a expansão da criminalidade em Cidade de Deus [...] merece ser saudado'" (2006, p. 38). Uma nota laudatória que, à primeira vista, configura-se como uma reverência ao romance, e de fato o é, porém traz também em seu bojo, veladamente se se preferir, uma quase imperceptível manifestação do processo de deturpação a que venho fazendo menção.

O livro de Paulo Lins, sim, merece ser saudado como um acontecimento, porém afirmar que se trata de um romance "sobre a expansão da criminalidade em Cidade de Deus" (Rocha, 2006, p. 38) não contempla plenamente as possibilidades de leitura do mesmo. Afirmações como essa, contudo, estão espalhadas por livros e periódicos em maior ou menor grau, e, de fato, representam uma das linhas do atual estágio dos estudos da "Literatura Marginal". Ou seja, críticos consagrados "pisando em ovos" quando o assunto, que já não se pode ignorar, é discutido, para não acusarem as obras de inferiores esteticamente, mas que, inevitavelmente, deixam transparecer que não podem, não foram (des)treinados para verem além da superficial ideia de "expansão da criminalidade". Inadvertidamente, ou não, tais modelos de abordagem também terminam por, ainda que sutilmente, corroborar a manutenção do processo.

No caso específico dos Racionais $\mathrm{MC}^{\prime}$ s, esse modelo de abordagem, com ligeiras variantes, apresenta-se, em maior ou menor grau, em muitos dos trabalhos até agora publicados. O resgate da questão racial no clipe-homenagem a Marighella é uma amostra de como o grupo lida com ela. Basta ouvir os discos dos Racionais $M C^{\prime}$ 's para se notar que a questão racial é não somente tema, mas o próprio corpus, fôlego, DNA, enfim, é tudo na produção do grupo. Contudo, essa questão tem sido relegada a segundo plano por uma parte dos estudiosos que se

\footnotetext{
${ }^{16}$ Obviamente que há raps que se enquadram nesta categoria.
} 
dedicam a sua produção. Somente à guisa de amostragem menciono os trabalhos pioneiros de Walter Garcia, que, segundo Ricardo Teperman, é "talvez o principal especialista em Racionais MC's na Academia" (2015, p. 77). ${ }^{17}$ Por meio de uma análise de quatro raps, compostos em diferentes períodos, Garcia propõe "Elementos para a crítica estética do Racionais MC's". Tratase de um "cotejo dos raps com obras literárias ou com canções que trabalham experiências semelhantes" (2013, p. 82) com o intuito de "pesquisar a constelação à qual o trabalho do Racionais [...] se integra" (2013, p. 83). A partir da máxima "em São Paulo, Deus é uma nota de cem" (Racionais MC's, 2002), Garcia (2013) rastreia o leitmotiv da valorização do capital em detrimento de quaisquer outros valores, elenca os nomes de Machado de Assis, José Lins do Rego, João dos Santos Rosa e Guimarães Rosa, em cujos trabalhos o tema se faz presente e aproxima o rap "Hey Boy" (Racionais MC's, 1990) a Lima Barreto por intermédio do mesmo motivo. Em seguida, alude a Manuel Bandeira, sempre buscando pontos em comum entre essas obras e o rap dos Racionais MC's.

Os pontos de interseção selecionados, porém, mostram-se arbitrários, se analisados mais detidamente, e parecem ser resultado daquela tentativa mencionada previamente de demonstrar que sua produção tem qualidade e que pode ser elencada junto a nomes consagrados. Arbitrários porque o obviamente frutífero resultado das comparações poderia ter sido alcançado por meio do emprego de outros motivos quaisquer. Apesar de correta, a advertência de Garcia - de que "não se trata, porém, de apontar influências [...] nem se trata de desconhecer que há diferenças" (2013, p. 82) -, de fato o cânon nesse caso se revela como uma espécie de chave-mestra usada para decodificar a criptografia desse algoritmo das ruas chamado rap. Esse procedimento é o mais aceito, costumeiro e disseminado nos nossos meios. É o que se espera de nós e é empregado por todos nós e, no caso específico aqui, acaba sendo o que legitima o arrojo de apresentar o rap dos Racionais MC's como tópico acadêmico.

No caso de "O bicho", poema de Bandeira usado como contraponto a "Um homem na estrada" (Racionais MC's, 1993), Garcia (2013, p. 92) declara que, por ser uma poesia completa em sua forma, "deve ser tomado com reserva o seu cotejo com um episódio cantado em apenas quatro versos". O cotejo, que é válido, poderia ser enriquecido se tomado com reservas devido a questões muito mais profundas e relacionadas à finalidade de tal comparação e suas possíveis consequências. Uma delas é essa tática de elevar o rap ao patamar dos canônicos para "tornar mais visíveis algumas características" (Garcia, 2013, p. 92). Para cada um dos raps que analisa, Garcia busca um ponto de comparação em um nome canônico em que se apoiar. Assim, o cânon legitima os Racionais MC's e, dessa maneira, quiçá, por meio dessa tradução, o/a acadêmico/a desabituado/a a escutar rap e pouco interessado/a em fazê-lo, ${ }^{18}$ preste um pouco mais de atenção a essa produção: o que de fato vem sucedendo. Em todo caso, não é o método de Garcia o que está em questão aqui, muito menos o mérito de suas pesquisas.

A questão racial, que tinha sido deixada de lado, é em parte contemplada no último rap abordado: "Negro Drama" (Racionais MC's, 2002), cujo próprio título torna impraticável uma fuga ao tema, presente em todos os raps do grupo. Em determinado trecho de seu artigo, Garcia (repetindo a fórmula empregada na análise do clipe-homenagem a Marighella, ou seja, reconhecer a existência da questão negra e em seguida reservar-lhe um segundo plano ${ }^{19}$ ) trata o assunto tangencialmente, valendo-se de comentários de Maria Rita Kehl (2000) e Bruno Zeni (2004), além de

\footnotetext{
${ }^{17}$ Os critérios considerados por Teperman (2015) para chegar a tal conclusão não são claros, porém os trabalhos de Garcia são, de fato, de longe os mais citados pelos que se aventuram a estudar o rap dos Racionais MC's.

${ }^{18}$ Kehl também atenta para esse fato ao questionar: “Como gostar dessa música que não se permite alegria nenhuma, exaltação nenhuma? Como escutar essas letras intimidatórias, acusatórias, frequentemente autoritárias, embaladas pelo ritmo que lembra um campo de trabalhos forçados ou a marcha dos detentos ao redor do pátio, que os garotos dançam de cabeça baixa, rosto quase escondido pelo capuz do moletom e os óculos escuros, curvados, como se tivessem ainda nos pés as correntes da escravidão?” (Kehl, 2000, p. 214).

${ }^{19}$ Conforme consta: "O rap e o clipe do Racionais MC's se engajam na batalha pela memória das lutas revolucionárias que se posicionavam contra a ditadura e também contra o sistema capitalista, 'abrindo a via para a construção de um regime alternativo, socialista.' Acrescente-se uma terceira frente de combate, contra a herança escravista de segregação racial e de superexploração do trabalho dos negros e das negras" (Botelho, Garcia e Rosa, 2015, s.p.). Note-se como à questão negra é reservada, sutilmente, a terceira frente de batalha e não a primeira. Basta ver o clipe com outra perspectiva para notar que a exaltação de figuras negras famosas pela luta pelos direitos das populações negras sugere que o ocorre no clipe é justamente o oposto.
} 
discorrer sobre os dois elementos que escolheu para fazer o contraponto deixando em segundo plano o rap dos Racionais MC's. É impossível afirmar se o recurso é intencional ou não, porém é inegável que há um apagamento da questão racial. Como já pontuou Cornel West, "a dimensão racial do hip-hop é inevitável" (West, 2005, p. xii, tradução nossa), o que no caso do rap dos Racionais MC's sempre foi tema central. Também é impossível negar que o trabalho de Garcia termina por se configurar como um esforço, eximiamente executado, diga-se de passagem, de traduzir o rap dos Racionais MC's e apresentá-lo ao mundo acadêmico de maneira mais atrativa. E somente para providenciar mais um exemplo, podemos trazer à baila outro artigo do pesquisador no qual -, apesar de Tricia Rose $(1994)^{20}$ e Russel Potter (1995) ${ }^{21}$ já terem demonstrado a inadequação e inaptidão do emprego de teorias musicais ocidentais ao estudo da música negra, em geral, e apesar de o fato de que "toda a história da música negra é marcada por situações conflituosas com a 'boa música' da sociedade branca" (Tella, 1999, p. 61) -, Garcia (2011) apresenta versos de um rap em partitura. Essas práticas acabam por não enveredar por "o desafio de examinar expressões culturais negras como mais do que meramente documentais, políticas, como protesto ou como algo exótico" (West, 2005, p. xii, tradução nossa). Em uma análise que propõe "elementos para a crítica estética" de uma manifestação artística que tem sua estética intrínseca e declaradamente proveniente da questão racial, esta se torna elemento periférico e descartável e o rap, cujo valor é eximiamente apresentado em linguagem e metodologia acadêmicas, apresenta-se sem cor.

Como fica demonstrado, o branqueamento simbólico é um processo ainda em andamento e que parece seguir o mesmo modo de operação da tentativa de branqueamento físico (que falhou). Dois recursos principais são utilizados. Primeiro, trata-se de apagar a figura histórica de qualquer indivíduo negro ou, como no reconhecido caso de Machado de Assis, de qualquer traço afrodescendente (físico ou simbólico), já pela erradicação de sua presença nos anais da história, já por uma alteração da cor de sua tez no imaginário popular, como ocorreu no caso de Marighella, por exemplo. Aqueles autores que escapam a esse filtro passam pela segunda fase do processo, que é a abordagem e conseguinte interpretação de sua produção por meio de modelos brancos e que, via de regra, geram o efeito descrito por Tricia Rose:

Para muitos críticos culturais, uma vez que uma prática cultural negra ocupa um lugar de destaque dentro do sistema de mercadorias, esta não é mais considerada uma prática negra - é uma prática "popular" cujas prioridades culturais negras e distintas visões negras ou são "um ponto de origem" tomado por certo, uma "técnica" isolada, ou são tornadas invisíveis (1994, p. 83, tradução nossa).

Tricia Rose acreditava que tal fato não aconteceria com o rap, porém, como este trabalho demonstra, devido ao processo que ocorre no Brasil, aqui ele já está em andamento.

\section{Referências}

AZEVEDO, Reinaldo (2007). Por que um certo Mano Brown é superior a Cristo. Veja, 9 fev. Disponível em: https:/ / bit.ly/35qVr7u. Acesso em: 11 dez. 2019.

AZEVEDO, Reinaldo (2012). Mano Brown, o maior intelectual da esquerda contemporânea, celebra Marighella, o arrancador de perna e defensor do assassinato de inocentes. Veja, 21 maio 2012. Disponível em: https:// bit.ly/2QoEK8z. Acesso em: 9 fev. 2016.

BOTELHO, Guilherme; GARCIA, Walter; ROSA, Alexandre (2015). Três raps de São Paulo: "Política" (1994), “O menino do morro" (2003) e "Mil faces de um homem leal (Marighella)" (2012). Nuevo Mundo Mundos Nuevos, Paris, $1^{\circ}$ dez. Disponível em: http://journals.openedition.org/nuevomundo/68717. Acesso em: 9 mar. 2018.

\footnotetext{
20 “ao contrário da complexidade da música clássica ocidental, que é primariamente representada em suas estruturas melódicas e harmônicas, a complexidade do rap, como de muitas músicas afrodiaspóricas, está na densidade rítmica e percussiva e na organização" (Rose, 1994, p. 65, tradução nossa).

21 “A música afro-americana está fundamentalmente em desacordo com a música ocidental, com sua obsessão pela reprodução precisa da notação musical” (Potter, 1995, p. 27, tradução nossa).
} 
CAPRIGLIONE, Laura; BERGAMO, Marlene (2012). Sem-teto Racionais. Folha de S. Paulo. Disponível em: http://www1.folha.uol.com.br/fsp/cotidiano/44179-sem-teto-racionais.shtml. Acesso em: 21 mai. 2012.

CARONE, Iray; BENTO, Maria Aparecida Silva (Org.) (2002). Psicologia social do racismo: estudos sobre branquitude e branqueamento no Brasil. Rio de Janeiro: Vozes.

DÁVILA, Jerry (2003). Diploma of whiteness: race and social policy in Brazil, 1917-1945. Durham: Duke University Press.

DUARTE, Eduardo de Assis (2007). Machado de Assis's african descent. Research in African Literatures, Bloomington, v. 38, n. 1, p 134-151. Disponível em: https://muse.jhu.edu/article/209533/pdf. Acesso em: 11 dez. 2019.

DUTRA, Paulo (2015). A violenta palavra cantada dos Racionais MC's. In: VÁSQUEZ, Hernán Gabriel; SIRI, Laura (Orgs.). Representaciones discursivas de la violencia, la otredad y el conflicto social en Latinoamérica. Buenos Aires: UBA. E-book. p. 291-303. Disponível em: https:/ / bit.ly/2rTKldx. Acesso em: 11 dez. 2019.

GARCIA, Walter (2011). Sobre uma cena de "Fim de semana no parque", do Racionais MC's. Estudos Avançados, São Paulo, v. 25, n. 71, p. 221-235, jan./abr. Disponível em: https://bit.ly/35jT2eU. Acesso em: 11 dez. 2019.

GARCIA, Walter (2013). Elementos para a crítica da estética do Racionais MC's (1990-2006). Idéias, Campinas, v. 4, n. 7, p. 81-109, 20 dez. Disponível em: https:// bit.ly/36qt3E2. Acesso em: 11 dez. 2019.

GATES JUNIOR, Henry Louis (1988). The signifying monkey: a theory of african-american literary criticism. New York: Oxford University Press.

KEHL, Maria Rita (2000). A fratria órfã: o esforço civilizatório do rap na periferia de São Paulo. In: KEHL, Maria Rita. Função fraterna. Rio de Janeiro: Relume Dumará. p. 209-244.

MAGALHÃES, Mário (2012). Marighella: o guerrilheiro que incendiou o mundo. São Paulo: Companhia das Letras.

MARIGHELLA (2012). Direção: Isa Grispun Ferraz. TC Filmes. Documentário. 100 minutos. Disponível em: https://youtu.be/1cbe8G4G-_g. Acesso em: 11 dez 2019.

MARIGHELLA, Carlos (1985). Manual of the urban guerilla. Tradução de Gene Hanrahan. Chapel Hill: Documentary Publications.

MEYER, Victor (1999). Marighella e a estratégia de luta contra a ditadura militar: evocações de velhos e novos tempos. In: NÓVOA, Cristiane; NÓVOA, Jorge (Orgs.). Carlos Marighella: o homem por trás do mito. São Paulo: Editora da Unesp. p. 257-271.

MIL faces de um homem leal (2012). Direção: Daniel Grispun. Preta Portê Filmes. Videoclipe. Disponível em: https://www.youtube.com/watch?v=5Os1zJQALz8. Acesso em: 11 dez. 2019.

MUNANGA, Kabengele (2004). Rediscutindo a mestiçagem no Brasil. Belo Horizonte: Autêntica.

NASCIMENTO, Jorge Luiz do (2006). Da ponte pra cá: os territórios minados dos Racionais MC's. Revista Eletrônica de Estudos Literários, Vitória, ano 2, n. 2, p. 1-28. Disponível em: https://bit.ly/2SUsu1a. Acesso em: 11 dez. 2019.

NASCIMENTO, Jorge Luiz do (2013). Cultura e consciência: a "função" do Racionais MC's. Z Revista Cultural Revista Virtual do Programa Avançado de Cultura Contemporânea, Rio de Janeiro, ano 5, n. 3. Disponível em: https:// bit.ly/37y06WT. Acesso em: 11 dez. 2019.

NASCIMENTO, Jorge Luiz do (2019). Violência policial, racismo e resistência: notas a partir da MPB. Contexto, Vitória, n. 35. Disponível em: https:// bit.ly/36txbTG. Acesso em: 11 dez. 2019.

POTTER, Russel A. (1995). Spectacular vernaculars: hip-hop and the politics of postmodernism. New York: State University of New York Press.

RACIONAIS MC's (1990). Holocausto urbano. São Paulo: Boogie Naipe. 1 CD.

RACIONAIS MC's (1993). Raio X do Brasil. São Paulo: Zimbabwe. 1 CD.

RACIONAIS MC's (2002). Nada como um dia após o outro. São Paulo: Cosa Nostra. 1 CD.

RACIONAIS MC's (2014). Cores e valores. São Paulo: Cosa Nostra. 1 CD. 
ROCHA, João César de Castro (2006). A guerra de relatos no Brasil contemporâneo. Ou “A dialética da marginalidade". Revista Letras, Santa Maria, n. 32, p. 27-70. Disponível em: https://bit.ly/2QKskXv. Acesso em: 11 dez. 2019.

ROSE, Tricia (1994). Black noise: rap music and black culture in contemporary America. Hanover: University Press of New England.

TELLA, Marco Aurélio Paz (1999) Rap, memória e identidade. In: ANDRADE, Elaine Nunes (Org.). Rap e educação. Rap é educação. São Paulo: Selo Negro. p. 55-64.

TEPERMAN, Ricardo (2015). Se liga no som: as transformações do rap no Brasil. São Paulo: Claro Enigma.

VITAL, Selma (2012). Quase brancos, quase pretos: representação étnico-racial no conto machadiano. São Paulo: Intermeios.

WELTER, Juliane Vargas; PUREZA, Fernando Cauduro (2014). O herói baiano e o herói da periferia: reapropriações de Carlos Marighella na canção brasileira contemporânea. Ciências E Letras, Porto Alegre, n. 56, p. 175-191, jul./dez.

WEST, Cornel (2005). Foreword. In: DARBY, Derrick; SHELBY, Tommie (Orgs.). Hip Hop and philosophy: rhyme 2 reason. Illinois: Carus Publishing Company. p. xi-xii.

ZENI, Bruno (2004). O negro drama do rap: entre a lei do cão e a lei da selva. Estudos avançados, São Paulo, v. 18, n. 50, p. 225-241, 1º abr. Disponível em: https:// bit.ly/2QowSnp. Acesso em: 11 dez. 2019. 